\title{
Effect of interventions based on regular physical activity on weight management in adolescents: a systematic review and a meta-analysis
}

Babak Moeini ${ }^{1}$, Forouzan Rezapur-Shahkolai ${ }^{2}$, Saeed Bashirian ${ }^{3}$, Amin Doosti-Irani $^{4}$, Maryam Afshari ${ }^{5}$ and Azam Geravandi ${ }^{*}$ (i)

\begin{abstract}
Background: Physical inactivity is one of the major risk factors for non-communicable diseases. This systematic review and meta-analysis aimed to assess the effects of educational interventions on promoting regular physical activity in adolescent weight management programs.

Methods: The relevant studies indexed in Embase, Web of Science, Scopus, and ProQuest databases were searched using keywords namely "Physical Activity, Adolescent, Weight Management, Body Mass Index (BMI), Randomized Controlled Trials, and Clinical Trial." Up to the end of March 2020, two authors independently screened the papers, extracted data, and assessed the methodological quality of the studies using Effective Public Health Practice Project (EPHPP) tool.

Results: Out of 12,944 initial studies, 14 met the inclusion criteria after screening the titles, abstracts, and full texts of the papers. The participants in these studies were aged between 6 and 18 years, and 13 studies included participants from both sexes. Moreover, eight of them were performed as a controlled clinical trial. The overall estimate of the difference showed that the interventions improved weight loss which is a statistically significant finding. The participants in the intervention group had a weight loss of $1.02 \mathrm{~kg}$ compared to the control group at a 95\% confidence interval (-4.794-0.222).

Conclusion: Published longitudinal data indicated that physical activity declines over the transition from adolescence to adulthood. Using the results of the study, policy-makers can design educational interventions using educational models and patterns.
\end{abstract}

Systematic review registration: PROSPERO registration number: CRD42020173869

Keywords: Physical activity, Adolescent, Weight management, Meta-analysis

\footnotetext{
* Correspondence: Geravandi_a88@yahoo.com

${ }^{5}$ Department of Public Health, School of Public Health, Hamadan University

of Medical Sciences, Hamadan, Iran

Full list of author information is available at the end of the article
}

(c) The Author(s). 2021 Open Access This article is licensed under a Creative Commons Attribution 4.0 International License, which permits use, sharing, adaptation, distribution and reproduction in any medium or format, as long as you give appropriate credit to the original author(s) and the source, provide a link to the Creative Commons licence, and indicate if changes were made. The images or other third party material in this article are included in the article's Creative Commons licence, unless indicated otherwise in a credit line to the material. If material is not included in the article's Creative Commons licence and your intended use is not permitted by statutory regulation or exceeds the permitted use, you will need to obtain permission directly from the copyright holder. To view a copy of this licence, visit http://creativecommons.org/licenses/by/4.0/. The Creative Commons Public Domain Dedication waiver (http://creativecommons.org/publicdomain/zero/1.0/) applies to the data made available in this article, unless otherwise stated in a credit line to the data. 


\section{Background}

Despite scientific advances in healthcare, a worldwide increase in the number of chronic diseases due to mechanical life and poor eating habits is witnessed [1]. In recent decades, the epidemiological trend of diseases has changed so that infectious diseases have decreased and lifestyle-related diseases have increased [2].

According to available statistics, about 1.2 billion people in the world are overweighed [3]. Low physical activity is one of the major factors causing obesity. The amount of daily physical activity (PA) decreases with age [4-7]. A study by Cooper and Goodman analyzed pooled accelerometer data from more than 27,000 children and adolescents and showed that only $9 \%$ of the male and $2 \%$ of the female participants meet the World Health Organization recommendation of daily 60-min moderate-to-vigorous PA [8]. Over the past three decades, the prevalence of obesity and overweight in children and adolescents around the world has increased rapidly [9, 10]. According to the Centers for Disease Control and Prevention, the prevalence of obesity and overweight among adolescents (12-19 years old) has increased by $20.6 \%$ [11].

A sedentary lifestyle is the reason for many noncommunicable diseases. Diseases such as primary hypertension, osteoporosis, and cardiovascular conditions, the effects of which appear at early and middle ages, are rooted in a sedentary lifestyle [12]. Regular physical activity, as an important health-promoting behavior, prevents or delays a variety of chronic illnesses and premature deaths, promotes mental health, reduces depressive and anxiety symptoms, and improves the quality of life [13-15]. Despite the benefits of physical activity, people in many countries, including Iran, do not engage in regular physical activity [16]. Hence, the World Health Organization (WHO) considers the level of physical activity (PA) as the first indicator of health in a society [17].

Currently, physical inactivity in young people is a big problem because the risk factors and unhealthy behaviors that contribute to heart disease in adulthood begin in childhood and adolescence [18]. Adolescence is the period of transition between childhood and adulthood and the level of physical activity decreases during this period [19]. Being a time-consuming and costly activity and fatigue from exercise prevent physical activity. Factors such as self-efficacy and support from others enhance physical activity in adolescents [20]. Adolescents, including students, are a justifiable group for assessing health-related behaviors because they constitute a large group in society [21]. A systematic review by Voskuil et al. [22] and a meta-analysis by Pearson et al. [23] assessed interventions to promote PA in adolescent girls in school and community settings.
Implementation of interventions is effective in improving the regular physical activity of adolescents and ensuring their health, as it can pave the way for the prevention of many diseases in adulthood. The main focus of these interventions is on weight management in adolescents through increasing regular physical activity. To the best of our knowledge, most weight-loss interventions and techniques are focused on the role of nutrition and obesity control in older people. There is a need for a systematic review of physical activity in adolescents. Studies have shown that interventions based on behavior change models and theory are more efficient to create a behavior change $[24,25]$. Thus, the main objective of the current systematic review was to assess the effect of educational interventions on promoting regular physical activity in adolescent weight management programs.

\section{Materials and methods}

This systematic review and meta-analysis is based on the PRISMA statement [26] and registered in PROSPERO (CRD42020173869).

\section{Search strategy}

The search was done in PubMed, Scopus, Em base, Science Direct, Web of Science, and Pro Quest databases. Using the population model, the intervention, comparison, results, and design of the PICOS study were examined in papers published before the end of March 2020. The search strategy focused on three themes: participants (adolescents), outcomes (physical activity and weight management), and study type (Randomized Controlled Trials and experimental studies). The articles' references were searched for reassurance. The Keywords derived from MeSH were "weight loss, weight management, obesity, adolescent, and randomized controlled trial." The search strategy in the PubMed database was performed according to Appendix 1, and the necessary changes were made according to the necessity in each one of the databases.

\section{Article selection criteria}

To study the entry and exit criteria of the study, the PICOS index (population under study, type of studies, types of interventions, and type of outcome) was used.

The population under study was the adolescent age group (between the ages of 11 and 19). The types of interventions included interventions conducted at individual, family, school, or hospital levels for adolescents. The types of studies were experimental and semi-experimental interventions and the subjects of studies were weight management interventions and increase of physical activity in different places. In addition, primary consequences in studies, i.e., increased physical activity, and secondary 
consequences, i.e., increased self-efficacy and change of attitudes and awareness, were examined. There was no publication date limitation and only studies published in English entered the study.

At first, all studies were reviewed by two researchers (AG and MA) based on the proposed search strategy, and all the obtained articles were entered into the EndNote software. Then duplicate items were removed in the EndNote. The title and summary of the relevant studies were independently examined by the two researchers in terms of relevance to the research question. The results obtained by them were matched and the differences were resolved by agreement or, if necessary, by a third researcher. To ensure that the study question was appropriate, the full text of the study would be reviewed and, if appropriate, the study question would be selected to assess the risk of bias in the next step.

\section{Statistical analysis}

The statistical heterogeneity across the results of the included studies was explored using the Chi-squared test and quantified using $I^{2}$ statistics. The $I^{2}$ values of $<50 \%$, $50-74 \%$, and $\geq 75 \%$ were considered as low, moderate, or high heterogeneity respectively $[29,30]$. Publication bias was evaluated visually by funnel plot; in addition, the Begg and Egger tests were used to examine statistical significance of this bias $[27,28]$.

\section{Summary measure}

The mean difference of the effect of the intervention on the weight loss was calculated for each included study. The change score approach was used to obtain the effect size because the correlation between before and after measurements was more than $1 / 2$. Meta-analysis was used to obtain the pooled effect size. The random-effects model was used to report the results of the metaanalysis [29] and the results were reported with a 95\% confidence interval. Statistical analysis was performed using Stata 11 (StataCorp, College Station, TX, USA).

\section{Results}

The initial search yielded 12,944 abstracts, out of which, 11,828 articles were excluded. The remaining 1116 articles were reviewed and 233 were found eligible for the study. Then, the full texts were reviewed independently by the two researchers and the selection agreement between the reviewers was excellent Cohen's kappa coefficient (0.739) [30]. The study selection process is illustrated in Fig. 1. Eventually, 14 studies were the meta-analysis phase [27-29, 31-41].

The strategies of the intervention in the studies were to hold training classes and film screening, counseling, practical training by a sports coach, motivational interviews, support from parents and peers, and school staff, application design, and use of Facebook groups.

The fourteen articles included eight RCT studies, one nRCT study, four CCT studies, and one experimental study. The total participants in these studies were 4437 individuals with age range between 6 and 18 years. The participants in thirteen studies were girls and boys [27$29,32-38]$, and one study was performed only on girls [41] (Table 1).

A quality assessment was performed and four articles had poor quality $[27,28,32,36]$, four articles had medium quality $[35,37,38,40]$, and six articles had high quality [29, 31, 33, 34, 39, 41]. Cohen's Kappa coefficient was used to evaluate the agreement between the two researchers when evaluating the quality of articles. The agreement between the two researchers was based on six components of the EPHPP tool. There was a good agreement between the researchers for attrition and a very good agreement was reached for the other components [42].

\section{Meta-analysis}

The main indicator studied in this work was the effect of interventions and the results were calculated with a 1.02 (95\% CI: 0.22, 4.79). A mean difference was used to combine the results of different studies. The overall estimate of the mean difference showed that the interventions had a statistically significant effect on weight loss.

The overall estimate of the mean difference showed that the interventions had a statistically significant effect on weight loss. The subjects in the intervention group had a weight loss of $1.02 \mathrm{~kg}$ compared with the control group. The meta-analysis estimate was obtained with a CI of 95\% (0.22-4.79). The statistical value of $I^{2}$ in this analysis was $88.9 \%$, which indicates the high heterogeneity of the study results (Figs. 2 and 3).

To minimize heterogeneity within the meta-analysis, studies were only included if they measured the same outcome measure (adjusted difference in mean values of PA/BMI in the intervention group compared with the control group at follow-up).

\section{Publication bias}

According to the funnel plot chart, studies do not seem to be distributed symmetrically around its axis. However, the results of the Begg statistical tests $(p=0.656)$ and Egger $(p=0.071)$ indicate that there is no publication bias.

\section{Discussion}

The objective of this systematic review was to investigate the impact and identify the types of interventions used to promote regular physical activity in adolescents' weight management programs. 


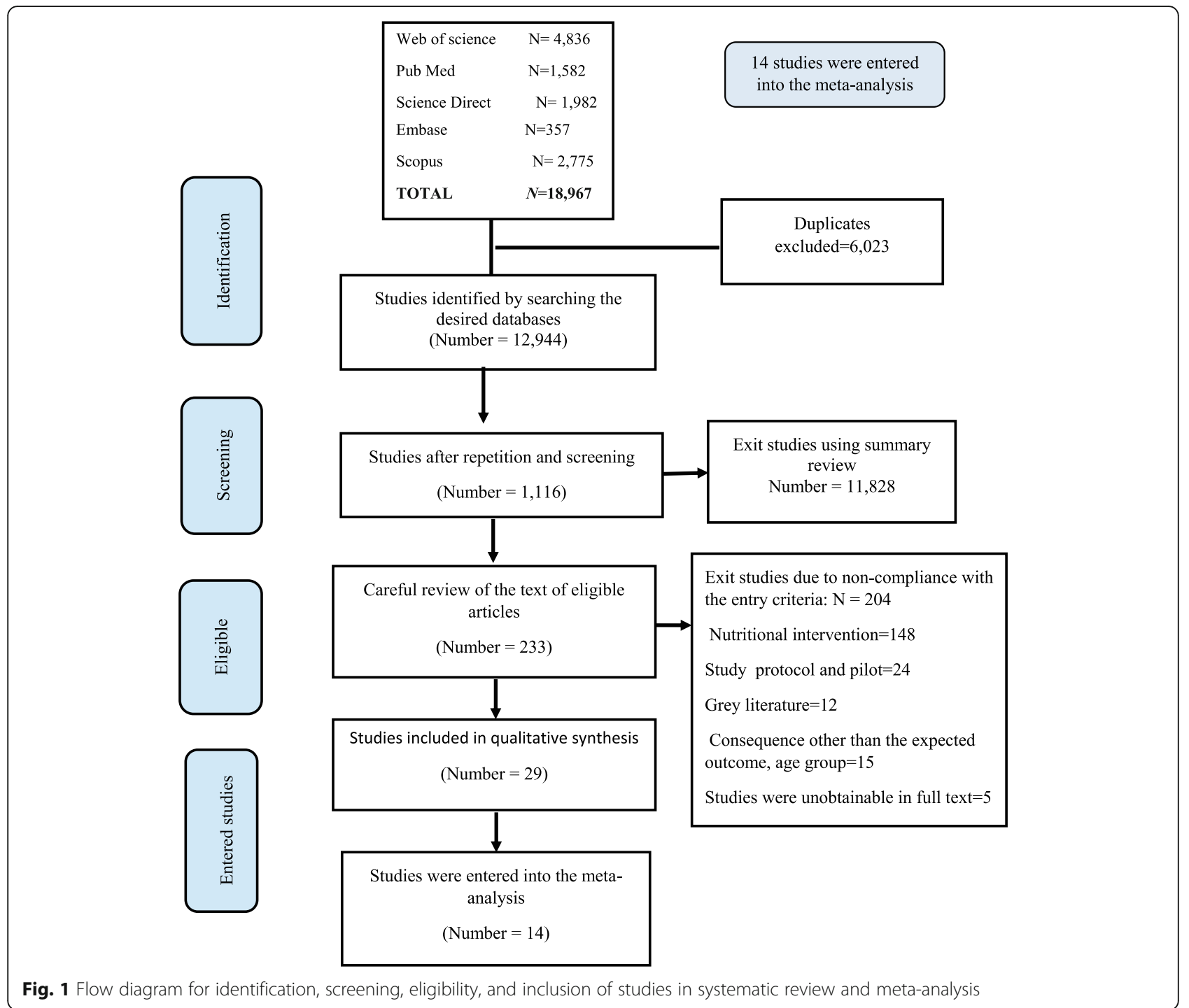

The interventions significantly increased the probability of regular physical activity and affected weight management and weight loss. Overweight and obesity are clear signs of an unhealthy lifestyle, a sedentary lifestyle, and an increased intake of high-calorie foods [43]. The trend of weight gain in children and adolescents (2-12 years) is more intensive than that of adults. Lifestyle changes from traditional to modern can lead to an increase in the prevalence of overweight and obesity [44].

Today, design and implementation of interventions based on health education theories are one of the most vital and specialized activities of health education and training professionals. A better understanding of behavior and the proper use of theories can enable us to use them intelligently and correctly [31].

Studies based on a theory of behavior change were significantly effective in increasing overall PA levels [45]. In the study of Rostami Moez et al., the intervention designed using a hybrid model was effective in preventing students from leaving physical activity programs [46].

Based on the classification of researchers, out of fourteen studies, five studies examined the effect of educational intervention on the level of regular physical activity and weight management in adolescents using health education and health promotion models $[29,34$, 39-41].

The theories and models used in this study included the transnational model and social and ecological cognitive theory. It turned out that social cognitive theory was more common than other models so that it was the basis of action in three of the studies [34, 40, 41].

In addition to using theories and patterns, one of the most important topics in health education today is interventions in health promotion environments. The studies conducted in the systematic review were conducted in three different places, including schools, places of 
Table 1 Summary of interventions to increase regular physical activity for weight management

\begin{tabular}{|c|c|c|c|c|c|c|c|c|}
\hline No. & $\begin{array}{l}\text { Author/Year/ } \\
\text { Location }\end{array}$ & $\begin{array}{l}\text { Clinical trial } \\
\text { design/ } \\
\text { randomization } \\
\text { strategy }\end{array}$ & Participants & $\begin{array}{l}\text { Intervention } \\
\text { description }\end{array}$ & $\begin{array}{l}\text { Percentage of } \\
\text { response and } \\
\text { duration of } \\
\text { intervention and } \\
\text { follow-up, theory } \\
\text { and model used }\end{array}$ & $\begin{array}{l}\text { Measurement of } \\
\text { consequences }\end{array}$ & Results & $\begin{array}{l}\text { Study } \\
\text { quality }\end{array}$ \\
\hline 1 & $\begin{array}{l}\text { Simon } \\
2008 \\
\text { France }\end{array}$ & $\begin{array}{l}\text { Random cluster } \\
\text { trial }\end{array}$ & $\begin{array}{l}\text { C: } N=479 ; \mathrm{l}: ~ N \\
=475 \\
\text { Range 9. 9- } \\
13.8 \text { years } \\
\text { BMl: } \\
\text { I= } 21.32 \\
(20.90 ; 21.75) \\
\mathrm{kg} / \mathrm{m}^{2} \\
\mathrm{C}=21.68 \\
(21.45 ; 21.91) \\
\mathrm{kg} / \mathrm{m}^{2} \\
\text { Target group= } \\
\text { Student (six- } \\
\text { graders) }\end{array}$ & $\begin{array}{l}\text { In addition to the } \\
\text { standard school } \\
\text { curriculum, the } \\
\text { intervention } \\
\text { program includes - } \\
\text { Three 50-min clas- } \\
\text { ses during the } \\
\text { week } \\
\text { - Holding sports } \\
\text { and cycling } \\
\text { competitions at } \\
\text { school and } \\
\text { encouraging and } \\
\text { supporting } \\
\text { parents and } \\
\text { educators in } \\
\text { improving the } \\
\text { level of physical } \\
\text { activity of } \\
\text { adolescents } \\
\text { through regular } \\
\text { sessions. }\end{array}$ & $\begin{array}{l}\text { Results were } \\
\text { obtained from } 848 \\
\text { students at the } \\
\text { end of the second } \\
\text { academic year. } 778 \\
\text { in } 3 \text { years and } 732 \\
\text { in } 4 \text { years } \\
\text { The model was } \\
\text { not used }\end{array}$ & $\begin{array}{l}\text { The primary } \\
\text { consequence is } \\
\text { change in body } \\
\text { mass index and } \\
\text { the secondary } \\
\text { consequence is } \\
\text { the promotion of } \\
\text { physical activity }\end{array}$ & $\begin{array}{l}\text { Change in BMI and } \\
\text { the level of } \\
\text { physical activity }\end{array}$ & Strong \\
\hline 2 & $\begin{array}{l}\text { Hagstr"omer } \\
2009 \\
\text { Sweden }\end{array}$ & Randomization & $\begin{array}{l}N=31 \\
\text { Exercisegroup } \\
(n=16) \\
\text { Controlgroup* } \\
(n=15) \\
\text { (Range 10-18 } \\
\text { years) } \\
\text { BMI: } I=31.9 \\
(5.4) ; C=33.4 \\
\text { (4.0) } \\
\text { Target group = } \\
\text { obese } \\
\text { adolescent }\end{array}$ & $\begin{array}{l}\text { Training sessions } \\
\text { included: A variety } \\
\text { of group activities } \\
\text { over } 13 \text { weeks ( } 1 \mathrm{~h} \\
\text { per week) } \\
\text { conducted by } \\
\text { management and } \\
\text { coaching } \\
\text { physiotherapist } \\
\text { (one brisk walking } \\
\text { session, } 6 \text { to } 9 \\
\text { strength training } \\
\text { sessions, and } 10 \text { to } \\
13 \text { swimming } \\
\text { sessions). }\end{array}$ & $\begin{array}{l}\text { The results were } \\
\text { assessed in } 16 \\
\text { adolescents in the } \\
\text { intervention group } \\
\text { and } 15 \text { adolescents } \\
\text { in the control } \\
\text { group } \\
\text { The model was } \\
\text { not used }\end{array}$ & $\begin{array}{l}\text { The primary } \\
\text { consequence is a } \\
\text { change in body } \\
\text { mass index and } \\
\text { the secondary } \\
\text { consequence is } \\
\text { the promotion of } \\
\text { physical activity }\end{array}$ & $\begin{array}{l}\text { Increased physical } \\
\text { activity } \\
p<0.05\end{array}$ & Weak \\
\hline 3 & $\begin{array}{l}\text { Ansari } \\
2010 \\
\text { Egypt }\end{array}$ & $\begin{array}{l}\text { Intervention in } \\
\text { the target } \\
\text { group of male } \\
\text { and female } \\
\text { students }\end{array}$ & $\begin{array}{l}N=160 \\
\text { l: } N=80((35 \\
\text { boys, } 45 \text { girls }) \\
C: N=80((35 \\
\text { boys, } 45 \text { girls) } \\
\text { Mange } \\
\text { age+15. } 7 \\
\text { years } \\
\text { BMl: } \\
\text { I=20.9 (4.1); C } \\
=21.2(3.6) \\
\text { Target group = } \\
\text { adolescent } \\
\text { school pupils }\end{array}$ & $\begin{array}{l}\text { Students were } \\
\text { offered two face- } \\
\text { to-face sessions } \\
\text { per week, each } \\
\text { lasting about } 30 \\
\text { min. There was } \\
\text { one PE hour per } \\
\text { week, which was } \\
\text { much less than the } \\
\text { international order } \\
\text { for PA for teens, } \\
\text { and attending } \\
\text { these physical edu- } \\
\text { cation classes were } \\
\text { not mandatory, } \\
\text { meaning students } \\
\text { could not attend. }\end{array}$ & $\begin{array}{l}\text { Data were } \\
\text { collected at two } \\
\text { time periods } \\
\text { before and three } \\
\text { months after the } \\
\text { intervention. } \\
\text { The model was } \\
\text { not used }\end{array}$ & $\begin{array}{l}\text { Primary outcome: } \\
\text { increased physical } \\
\text { activity secondary } \\
\text { outcome change } \\
\text { in the } \\
\text { anthropometric } \\
\text { index. }\end{array}$ & $\begin{array}{l}\text { The results of a } \\
\text { separate study of } \\
\text { male and female } \\
\text { students in which } \\
\text { the weight } \\
\text { decreased by } \\
12.5 \% \text { after three } \\
\text { months in the } \\
\text { intervention group } \\
\text { and increased by } \\
37.3 \% \text { in the } \\
\text { control group. }\end{array}$ & Strong \\
\hline 4 & $\begin{array}{l}\text { Lison } \\
2010 \\
\text { Spanish }\end{array}$ & $\begin{array}{l}\text { Three-arm } \\
\text { interventions: } \\
\text { two } \\
\text { intervention } \\
\text { groups and one } \\
\text { control group }\end{array}$ & $\begin{array}{l}2 \text { intervention } \\
\text { groups } \\
\text { 11: hospital, } \\
\text { clinic group- } \\
\text { based (GRX) N } \\
=45 \\
\text { 12: home-based } \\
\text { (HOX) N = 41 }\end{array}$ & $\begin{array}{l}\text { The training was } \\
\text { given to } \\
\text { participants in the } \\
\text { HOX group by a } \\
\text { physical education } \\
\text { instructor at the } \\
\text { hospital. The } \\
\text { program consisted }\end{array}$ & $\begin{array}{l}\text { The measurement } \\
\text { was performed in } \\
\text { two time periods } \\
\text { before and } 6 \\
\text { months after the } \\
\text { intervention. } \\
\text { The model was } \\
\text { not used }\end{array}$ & $\begin{array}{l}\text { Primary outcome: } \\
\text { increase physical } \\
\text { activity } \\
\text { intervention and } \\
\text { weight loss, and a } \\
\text { change in body } \\
\text { mass index in both } \\
\text { groups }\end{array}$ & $\begin{array}{l}\text { A significant } \\
\text { decrease in body } \\
\text { fat percentage and } \\
\text { body mass index } \\
\text { was observed in } \\
\text { both intervention } \\
\text { groups }(4,0.16), \\
\text { hospital-based }\end{array}$ & Weak \\
\hline
\end{tabular}


Table 1 Summary of interventions to increase regular physical activity for weight management (Continued)

\begin{tabular}{|c|c|c|c|c|c|c|c|c|}
\hline No. & $\begin{array}{l}\text { Author/Year/ } \\
\text { Location }\end{array}$ & $\begin{array}{l}\text { Clinical trial } \\
\text { design/ } \\
\text { randomization } \\
\text { strategy }\end{array}$ & Participants & $\begin{array}{l}\text { Intervention } \\
\text { description }\end{array}$ & $\begin{array}{l}\text { Percentage of } \\
\text { response and } \\
\text { duration of } \\
\text { intervention and } \\
\text { follow-up, theory } \\
\text { and model used }\end{array}$ & $\begin{array}{l}\text { Measurement of } \\
\text { consequences }\end{array}$ & Results & $\begin{array}{l}\text { Study } \\
\text { quality }\end{array}$ \\
\hline & & & $\begin{array}{l}\text { C: } N=24 \\
\text { BMI: HOX I= } \\
29.73 .7 \\
\text { GRX I = 28.5 } \\
3.8 \\
\text { C= } 29.23 .9 \\
\text { Target group = } \\
\text { Overweight } \\
\text { and obese } \\
\text { children and } \\
\text { adolescents, }\end{array}$ & $\begin{array}{l}\text { of } 5 \text { sessions per } \\
\text { week for } 6 \text { months } \\
\text { (120 sessions) and } \\
\text { the duration of } \\
\text { each session was } \\
\text { about } 60 \text { min. } 5 \\
\text { min for warm-up } \\
\text { and cooling (trac- } \\
\text { tion), } 35 \text { min of } \\
\text { moderate aerobic } \\
\text { activity, and } 20 \\
\text { min of resistance } \\
\text { training (low train- } \\
\text { ing exercises and } \\
\text { high repetition). }\end{array}$ & & & $\begin{array}{l}\text { group and; (4.4\%, } \\
0.23) \text {, located at } \\
\text { home, } p<.001\end{array}$ & \\
\hline 5 & $\begin{array}{l}\text { Maloney } \\
2012 \\
\text { Massachusetts }\end{array}$ & $\begin{array}{l}\text { Randomized } \\
\text { controlled trial }\end{array}$ & $\begin{array}{l}\text { Treatment } \\
\text { group }(n=33) \\
\text { Comparison } \\
\text { group ( } n=31) \\
\text { Ages of } 9 \text { and } \\
17 \text { years with a } \\
\text { body mass } \\
\text { index (BMI) of } \\
85-94 \% \\
\text { (overweight } \\
\text { category). } \\
\text { Range age = 9 } \\
\text { and } 17 \text { years } \\
\text { BMl } \\
\text { (percentage): I } \\
=96.57 \text { (3.69) } \\
\text { C=96.64 } \\
\text { (2.69) } \\
\text { Target group = } \\
\text { overweight } \\
\text { and obese } \\
\text { children and } \\
\text { adolescents }\end{array}$ & $\begin{array}{l}\text { Participants in the } \\
\text { therapy group } \\
\text { received a DDR X } \\
\text { dance package. } \\
\text { Each disc } \\
\text { contained more } \\
\text { than } 100 \text { songs of } \\
\text { different styles. } \\
\text { Participants were } \\
\text { randomly assigned } \\
\text { to the control } \\
\text { group, followed by } \\
\text { DDR software and } \\
\text { dance packs for } \\
\text { home use. }\end{array}$ & $\begin{array}{l}\text { The measurement } \\
\text { was performed } \\
\text { two periods before } \\
\text { and } 12 \text { weeks after } \\
\text { the intervention. } \\
\text { The model was } \\
\text { not used }\end{array}$ & $\begin{array}{l}\text { Preliminary results } \\
\text { of the activity } \\
\text { increase using } \\
\text { accelerometer } \\
\text { were evaluated }\end{array}$ & $\begin{array}{l}\text { There was no } \\
\text { significant change } \\
\text { between pre- and } \\
\text { post-intervention } \\
\text { weight gain. } 840 \text {. } \\
=p\end{array}$ & Weak \\
\hline 6 & $\begin{array}{l}\text { ॥ } \\
2014 \\
\text { China }\end{array}$ & $\begin{array}{l}\text { Nonrandom, } \\
\text { controlled trial }\end{array}$ & $\begin{array}{l}N=921 \\
\text { I: } N=388 ; C: N \\
=533 \\
\text { Aged } 7 \text { to } 15 \\
\text { years } \\
\text { BM / = } 19.59 \\
\mathrm{~kg} / \mathrm{m}^{2} \\
\text { BMl: I = } 19.12 \\
(4.28) \\
\text { BMl: C = } 19.93 \\
\text { (4.47) } \\
\text { Target group = } \\
\text { students (489 } \\
\text { boys and } 432 \\
\text { girls) }\end{array}$ & $\begin{array}{l}\text { During } 12 \text { weeks, } \\
\text { the intervention } \\
\text { group participated } \\
\text { in a multi- } \\
\text { component phys- } \\
\text { ical activity inter- } \\
\text { vention that } \\
\text { included:-Educa- } \\
\text { tion of physical } \\
\text { activity- } \\
\text { Programming for } \\
\text { overweight/obese } \\
\text { students, PA at } \\
\text { home-Lecture for } \\
\text { students and } \\
\text { parents }\end{array}$ & $\begin{array}{l}\text { The change in the } \\
\text { studied variables } \\
\text { (change in the } \\
\text { level of physical } \\
\text { activity and } \\
\text { weight) occurred } \\
\text { in two time } \\
\text { periods before the } \\
\text { intervention and } 3 \\
\text { months after the } \\
\text { intervention } \\
\text { Models used: } \\
\text { Ecological Social- } \\
\text { ecological model }\end{array}$ & $\begin{array}{l}\text { Changing the level } \\
\text { of physical activity } \\
\text { and BMI, HDL, LDL }\end{array}$ & $\begin{array}{l}\text { The change in BMl } \\
\text { in the intervention } \\
\text { group (0.02-0.02 } \\
\left.\mathrm{kg} / \mathrm{m}^{2}\right) \text { and } \\
\text { change (MVPA) } \\
\text { was significantly } \\
\text { different from the } \\
\text { control group ( } p= \\
0.001 \text { ). }\end{array}$ & Strong \\
\hline 7 & $\begin{array}{l}\text { Simon } \\
2014 \\
\text { France }\end{array}$ & $\begin{array}{l}\text { Cluster- } \\
\text { randomized } \\
\text { controlled trial }\end{array}$ & $\begin{array}{l}N=732 \\
\text { I: } N=275 ; C: N \\
=256 \\
\text { BMI }= \\
I=18.6(3.3) \\
C=18.8(3.5) \\
\text { Target group= } \\
\text { Students }\end{array}$ & $\begin{array}{l}\text { The standard the } \\
\text { curriculum } \\
\text { includes three } \\
\text { sessions of } 50 \\
\text { minutes of physical } \\
\text { training per week } \\
\text { plus intervention } \\
\text { based on the }\end{array}$ & $\begin{array}{l}\text { Following a } 30- \\
\text { month follow-up, } \\
\text { body mass index, } \\
\text { fat mass index, rec- } \\
\text { reational PA (active } \\
\text { movement at } \\
\text { home/school/work, } \\
\text { TV viewing time), }\end{array}$ & $\begin{array}{l}\text { Changes in } \\
\text { indicators studied } \\
\text { (BMl and fat) }\end{array}$ & $\begin{array}{l}\text { The change was } \\
\text { more than } 1 \text { week } \\
\text { on TVT during the } \\
\text { study with a } \\
\text { change in } \\
\text { additional BMl and } \\
\text { FMl of more than } \\
0.7 \mathrm{~kg} / \mathrm{m}^{2} \text {. The }\end{array}$ & Medium \\
\hline
\end{tabular}


Table 1 Summary of interventions to increase regular physical activity for weight management (Continued)

\begin{tabular}{|c|c|c|c|c|c|c|c|c|}
\hline No. & $\begin{array}{l}\text { Author/Year/ } \\
\text { Location }\end{array}$ & $\begin{array}{l}\text { Clinical trial } \\
\text { design/ } \\
\text { randomization } \\
\text { strategy }\end{array}$ & Participants & $\begin{array}{l}\text { Intervention } \\
\text { description }\end{array}$ & $\begin{array}{l}\text { Percentage of } \\
\text { response and } \\
\text { duration of } \\
\text { intervention and } \\
\text { follow-up, theory } \\
\text { and model used }\end{array}$ & $\begin{array}{l}\text { Measurement of } \\
\text { consequences }\end{array}$ & Results & $\begin{array}{l}\text { Study } \\
\text { quality }\end{array}$ \\
\hline & & & Adolescents & $\begin{array}{l}\text { dynamic } \\
\text { interaction } \\
\text { between PA } \\
\text { factors and } \\
\text { targeting } \\
\text { individuals, family } \\
\text { and their peers, } \\
\text { and their living } \\
\text { environment to } \\
\text { promote the } \\
\text { adoption of an } \\
\text { active lifestyle at } \\
\text { home. }\end{array}$ & $\begin{array}{l}\text { attitude toward PA } \\
\text { in adolescents } \\
\text { were measured. } \\
\text { The model was } \\
\text { not used }\end{array}$ & & $\begin{array}{l}\text { introduction of TVT } \\
\text { changes in the } \\
\text { models reduced } \\
\text { the effect of the } \\
\text { intervention on } \\
\text { additional BMI and } \\
\text { FMI by } 34.8 \% \text { and } \\
27.4 \% \text {, respectively. }\end{array}$ & \\
\hline 8 & $\begin{array}{l}\text { Galena } \\
2014 \\
\text { France }\end{array}$ & $\begin{array}{l}\text { Randomized- } \\
\text { controlled study }\end{array}$ & $\begin{array}{l}N=54 \\
(28 \text { in the } \\
\text { SWLP group, } \\
26 \text { in the SWLP } \\
+\mathrm{Ml} \text { group } \\
\text { Ages of } 11 \text { and } \\
18 \text { years } \\
\mathrm{BM} /=29.57 \\
\mathrm{~kg} / \mathrm{m}^{2} \\
\mathrm{SWLP}+\mathrm{M} \mathrm{I=} \\
29.56 \pm 4.75 \\
\mathrm{SWLP}=29.59 \\
\pm 5.92 \\
\text { Target group= } \\
\text { obese } \\
\text { adolescents }\end{array}$ & $\begin{array}{l}\text { Phase 1, making } \\
\text { participant's } \\
\text { acquaintance and } \\
\text { building awareness } \\
\text { Phase 2, } \\
\text { Alternatives and } \\
\text { problem solving } \\
\text { Phase 3, Goal } \\
\text { setting and } \\
\text { agenda-setting } \\
\text { Phase 4, Behavior } \\
\text { modification } \\
\text { consequences and } \\
\text { perspectives } \\
\text { Behavior change } \\
\text { feedback }\end{array}$ & $\begin{array}{l}\text { Allocated to SWLP } \\
\text { group }(n=34) \\
\text { Analyzed }(n=28) \\
\text { During } 6 \text { months } \\
\text { Allocated to SWLP } \\
+ \text { MI }(n=28) \\
\text { Analyzed }(n=26)\end{array}$ & $\begin{array}{l}\text { Change in BMI } \\
\text { Change in PA } \\
\text { Change in } \\
\text { motivational } \\
\text { regulations } \\
\text { Change in } \\
\text { perceived } \\
\text { competence }\end{array}$ & $\begin{array}{l}\text { No differential } \\
\text { change over time } \\
\text { was found for the } \\
\text { SWLP + MI group } \\
\text { as compared to } \\
\text { the SWLP group, } \\
\text { suggesting a } \\
\text { similar increase for } \\
\text { both groups on } \\
\text { this variable ( } p=\text {. } \\
\text { 34). }\end{array}$ & Strong \\
\hline 9 & $\begin{array}{l}\text { Direito } \\
2015 \\
\text { New Zealand }\end{array}$ & $\begin{array}{l}\text { 3-arm parallel } \\
\text { RCT }\end{array}$ & $\begin{array}{l}N=51(I: N= \\
16 ; C: N=18) \\
\text { Range age = } \\
14-17 \\
\text { BM I = 22.9 } \\
(\text { SD 4.3) kg/m² } \\
\text { Zombies, Run } \\
=23.17(3.60) \\
\text { Get running = } \\
21.85(3.14) \\
C=23.43 \\
\text { (5.56) } \\
\text { Target group= } \\
\text { adolescents }\end{array}$ & $\begin{array}{l}\text { Use commercially } \\
\text { available } \\
\text { applications. } \\
\text { An 8-week training } \\
\text { program }\end{array}$ & $\begin{array}{l}\text { Measured in two } \\
\text { stages before and } \\
2 \text { months later } \\
\text { The model was } \\
\text { not used }\end{array}$ & $\begin{array}{l}\text { Primary outcome: } \\
\text { cardiac and } \\
\text { respiratory } \\
\text { preparedness } \\
\text { secondary } \\
\text { outcomes: PA } \\
\text { levels (acceleration } \\
\text { and self-reporting), } \\
\text { pleasure, psycho- } \\
\text { logical satisfaction, } \\
\text { self-efficacy and } \\
\text { acceptance, and } \\
\text { program usability. }\end{array}$ & $\begin{array}{l}\text { There was no } \\
\text { intervention effect } \\
\text { in the initial result } \\
\text { using any of the } \\
\text { programs. } \\
\text { Compared to } \\
\text { control, the fitness } \\
\text { test time is - } 28.4 \\
\text { seconds shorter } \\
\text { and for the all- } \\
\text { round program } \\
\text { group and - } 24.7 \mathrm{~s} \\
\text { for the unconven- } \\
\text { tional program } \\
\text { group. }\end{array}$ & Weak \\
\hline 10 & $\begin{array}{l}\text { Ruotsalainen } \\
2015 \\
\text { Finland }\end{array}$ & $\begin{array}{l}\text { Three-arm } \\
\text { randomized } \\
\text { controlled trial }\end{array}$ & $\begin{array}{l}(\mathrm{Fb}+\mathrm{Act}, \quad= \\
15) \\
(\text { Feb, }=16) \\
\text { Control group } \\
(=15) . \\
\mathrm{BM} /=28.1 \\
(\mathrm{SD} 5.7) \\
\mathrm{Fb}+\mathrm{Act}= \\
29.7(8.1) \\
\mathrm{Fb}=27.5(4.2) \\
\mathrm{C}=27.0(3.8) \\
\text { Target group }= \\
\text { obese } \\
\text { adolescents }\end{array}$ & $\begin{array}{l}12 \text { weeks of } \\
\text { Facebook } \\
\text { consultation and } \\
\text { self-assessment of } \\
\text { physical activity }\end{array}$ & $\begin{array}{l}\text { Assess the level of } \\
\text { physical activity } \\
\text { before and } 3 \\
\text { months after the } \\
\text { intervention } \\
\text { The model was } \\
\text { not used }\end{array}$ & $\begin{array}{l}\text { Physical activity } \\
\text { and weight } \\
\text { control }\end{array}$ & $\begin{array}{l}\text { No intervention } \\
\text { effect was } \\
\text { observed in terms } \\
\text { of changes in } \\
\text { physical activity } \\
\text { level or BMl from } \\
\text { the beginning to } \\
12 \text { weeks after the } \\
\text { intervention } \\
\text { among the } \\
\text { intervention and } \\
\text { control group. }\end{array}$ & Medium \\
\hline 11 & $\begin{array}{l}\text { Chen } \\
2016 \\
\text { Taiwan }\end{array}$ & $\begin{array}{l}\text { Randomized } \\
\text { controlled trial }\end{array}$ & $\begin{array}{l}N=50 \\
\mathrm{I}: N=25 ; C: N \\
=25\end{array}$ & $\begin{array}{l}\text { The physical } \\
\text { activity program } \\
\text { included a variety }\end{array}$ & $\begin{array}{l}\text { The measurement } \\
\text { was performed in } \\
\text { three stages before }\end{array}$ & $\begin{array}{l}\text { Physical activity } \\
\text { Body mass index } \\
\text { and cardiovascular }\end{array}$ & $\begin{array}{l}\text { The physical } \\
\text { activity program } \\
\text { improved }\end{array}$ & Medium \\
\hline
\end{tabular}


Table 1 Summary of interventions to increase regular physical activity for weight management (Continued)

\begin{tabular}{|c|c|c|c|c|c|c|c|c|}
\hline No. & $\begin{array}{l}\text { Author/Year/ } \\
\text { Location }\end{array}$ & $\begin{array}{l}\text { Clinical trial } \\
\text { design/ } \\
\text { randomization } \\
\text { strategy }\end{array}$ & Participants & $\begin{array}{l}\text { Intervention } \\
\text { description }\end{array}$ & $\begin{array}{l}\text { Percentage of } \\
\text { response and } \\
\text { duration of } \\
\text { intervention and } \\
\text { follow-up, theory } \\
\text { and model used }\end{array}$ & $\begin{array}{l}\text { Measurement of } \\
\text { consequences }\end{array}$ & Results & $\begin{array}{l}\text { Study } \\
\text { quality }\end{array}$ \\
\hline & & & $\begin{array}{l}\text { Age range of } \\
12-15 \text { years } \\
\text { BMI= } \\
I=27.902 .71 \\
C=29.983 .97 \\
\text { Target group= } \\
\text { Obese young } \\
\text { adolescents }\end{array}$ & $\begin{array}{l}\text { of moderate- } \\
\text { intensity exercises } \\
\text { four times a week } \\
\text { for } 40 \text { min ( } 5 \text { min } \\
\text { to warm up and } \\
\text { cool down, } 30 \text { mi- } \\
\text { nutes for the main } \\
\text { workout) for } 3 \\
\text { months. Each par- } \\
\text { ticipant received a } \\
\text { physical activity } \\
\text { booklet with three } \\
\text { sections: a warm- } \\
\text { up, instruction } \\
\text { manual, an exer- } \\
\text { cise description, } \\
\text { and a daily exer- } \\
\text { cise newspaper. }\end{array}$ & $\begin{array}{l}\text { the intervention, } \\
\text { one week later and } \\
3 \text { months after the } \\
\text { intervention } \\
\text { The model was } \\
\text { not used }\end{array}$ & function & $\begin{array}{l}\text { participants' fitness } \\
\text { and obesity status. }\end{array}$ & \\
\hline 12 & $\begin{array}{l}\text { HAM } \\
2016 \\
\text { Butter }\end{array}$ & $\begin{array}{l}\text { Experimental } \\
\text { study }\end{array}$ & $\begin{array}{l}N=75 \\
\text { I: } N=48 ; C: N \\
=27 \\
\text { Range age = } \\
8-13 . \\
\text { BMI= } \\
I=24.35(2.73) \\
C=24.22 \\
(2.24) \\
\text { Target group = } \\
\text { overweight/ } \\
\text { obese children }\end{array}$ & $\begin{array}{l}\text { The TTM-based } \\
\text { sports counseling } \\
\text { intervention group } \\
\text { consisted of } 8 \text { ses- } \\
\text { sions over a } 3- \\
\text { month period (4 } \\
\text { consecutive weeks } \\
\text { for the first month } \\
\text { and } 2 \text { weeks for } \\
\text { the next week). } \\
\text { Each individual } \\
\text { counseling session } \\
\text { lasted } 30 \text { min. }\end{array}$ & $\begin{array}{l}\text { TTM model for } \\
\text { measuring in } 2 \\
\text { time periods } \\
\text { before the } \\
\text { intervention and } 6 \\
\text { months after the } \\
\text { intervention was } \\
\text { used. }\end{array}$ & $\begin{array}{l}\text { Changes in } \\
\text { physical activity } \\
\text { were based on } \\
\text { model structures } \\
\text { (behavioral } \\
\text { change, self- } \\
\text { efficacy), blood } \\
\text { sugar, and BMl. }\end{array}$ & $\begin{array}{l}\text { Self-efficacy } \\
\text { increased } \\
\text { significantly in the } \\
\text { experimental } \\
\text { group. According } \\
\text { to the change } \\
\text { steps, } 36.2 \% \text { of the } \\
\text { experimental } \\
\text { group performed } \\
\text { at least one stage } \\
\text { of their exercise } \\
\text { behavior } \\
\text { compared to } \\
17.4 \% \text { of the } \\
\text { control group. }\end{array}$ & Strong \\
\hline 13 & $\begin{array}{l}\text { Hollis } \\
2016 \\
\text { Australia }\end{array}$ & $\begin{array}{l}\text { School-based } \\
\text { Randomized } \\
\text { controlled trial }\end{array}$ & $\begin{array}{l}N=1150 \\
\text { I; } N=425 ; C: N \\
=560 \\
\text { (Mean age }=12 \\
\text { years) } \\
\text { BMI= } \\
I=19.90(3.59) \\
C=20.19 \\
(3.81) \\
\text { Target group = } \\
\text { children and } \\
\text { adolescents }\end{array}$ & $\begin{array}{l}\text { The school } \\
\text { intervention } \\
\text { involves seven } \\
\text { strategies for } \\
\text { physical activity } \\
\text { that include the } \\
\text { following: } \\
\text { Curriculum } \\
\text { (strategy to } \\
\text { maximize physical } \\
\text { activity in physical } \\
\text { education training, } \\
\text { student physical } \\
\text { activity programs, } \\
\text { an improved } \\
\text { school exercise } \\
\text { program). 2. } \\
\text { School } \\
\text { environment } \\
\text { (physical activity } \\
\text { during school } \\
\text { breaks, school } \\
\text { policy change). }\end{array}$ & $\begin{array}{l}\text { The measurements } \\
\text { were made in the } \\
\text { three-time periods. } \\
\text { Before, } 12 \text { months, } \\
\text { and } 24 \text { months } \\
\text { after the } \\
\text { intervention } \\
\text { SDT and socio- } \\
\text { ecological theory } \\
\text { was used. }\end{array}$ & $\begin{array}{l}\text { Changing physical } \\
\text { activity Changing } \\
\text { BMI }\end{array}$ & $\begin{array}{l}\text { After the weight } \\
\text { loss intervention } \\
\text { and BMl, the } \\
\text { students who were } \\
\text { in the intervention } \\
\text { group did not } \\
\text { recover despite } \\
\text { the increase in } \\
\text { their physical } \\
\text { activity. }\end{array}$ & Medium \\
\hline 14 & $\begin{array}{l}\text { Bagherniya } \\
2018 \\
\text { Iran }\end{array}$ & $\begin{array}{l}\text { Randomized } \\
\text { controlled trial }\end{array}$ & $\begin{array}{l}N=172 \\
\text { I: } N=87 ; C: N \\
=85 \\
\text { BMI }= \\
29.47(4.05) \mathrm{kg} / \\
\mathrm{m}^{2}\end{array}$ & $\begin{array}{l}\text { The activities of } \\
\text { this trial included: } \\
\text { sports, workshops, } \\
\text { private counseling } \\
\text { sessions in the } \\
\text { field of physical }\end{array}$ & $\begin{array}{l}\text { Measurements } \\
\text { were performed in } \\
\text { the time periods } \\
\text { before, the first } \\
\text { follow-up } 3 \text { to } 5 \\
\text { months later, and }\end{array}$ & $\begin{array}{l}\text { Changes in } \\
\text { physical activity } \\
\text { and BMl and } \\
\text { model structures }\end{array}$ & $\begin{array}{l}\text { PA and most of } \\
\text { the psychological } \\
\text { variables (self- } \\
\text { efficacy, social } \\
\text { support, and } \\
\text { intention) }\end{array}$ & Strong \\
\hline
\end{tabular}


Table 1 Summary of interventions to increase regular physical activity for weight management (Continued)

\begin{tabular}{|c|c|c|c|c|c|c|c|}
\hline $\begin{array}{l}\text { No. Author/Year/ } \\
\text { Location }\end{array}$ & $\begin{array}{l}\text { Clinical trial } \\
\text { design/ } \\
\text { randomization } \\
\text { strategy }\end{array}$ & Participants & $\begin{array}{l}\text { Intervention } \\
\text { description }\end{array}$ & $\begin{array}{l}\text { Percentage of } \\
\text { response and } \\
\text { duration of } \\
\text { intervention and } \\
\text { follow-up, theory } \\
\text { and model used }\end{array}$ & $\begin{array}{l}\text { Measurement of } \\
\text { consequences }\end{array}$ & Results & $\begin{array}{l}\text { Study } \\
\text { quality }\end{array}$ \\
\hline & & $\begin{array}{l}I=29.2(3.9 \\
C=27.2(2.9) \\
\text { Target group }= \\
\text { overweight } \\
\text { and obese girl } \\
\text { students }\end{array}$ & $\begin{array}{l}\text { activities, practical } \\
\text { and competitive } \\
\text { sports sessions, } \\
\text { family sports } \\
\text { sessions, text } \\
\text { messages, and } \\
\text { newspapers. }\end{array}$ & $\begin{array}{l}\text { the second follow- } \\
\text { up } 7 \text { months after } \\
\text { the intervention. } \\
\text { SDT model was } \\
\text { used }\end{array}$ & & $\begin{array}{l}\text { increased } \\
\text { significantly, the } \\
\text { hours of watching } \\
\text { television and } \\
\text { computer games } \\
\text { decreased } \\
\text { significantly ( } p< \\
0.001 \text { ). }\end{array}$ & \\
\hline
\end{tabular}

residence, and hospitals. Interventions to improve adolescent physical activity have shown that schools are better place to implement such interventions [47].

According to measurement indicators, physical activity increased in six studies; although, it was not possible to compare them due to the use of different measurement indicators and tools [28, 29, 31, 34-36]. The effectiveness of the intervention in short term ( 2 and 3 months) was examined in seven studies [28, 32-34, 36-38]. The duration of the study in four studies was 6 to 7 months [28, 34, 39, 41 ] and it was 12 to 48 months in the other three studies [31, 35, 40].

A review of physical activity promotion interventions from 2000 to 2011 showed that the different intervention

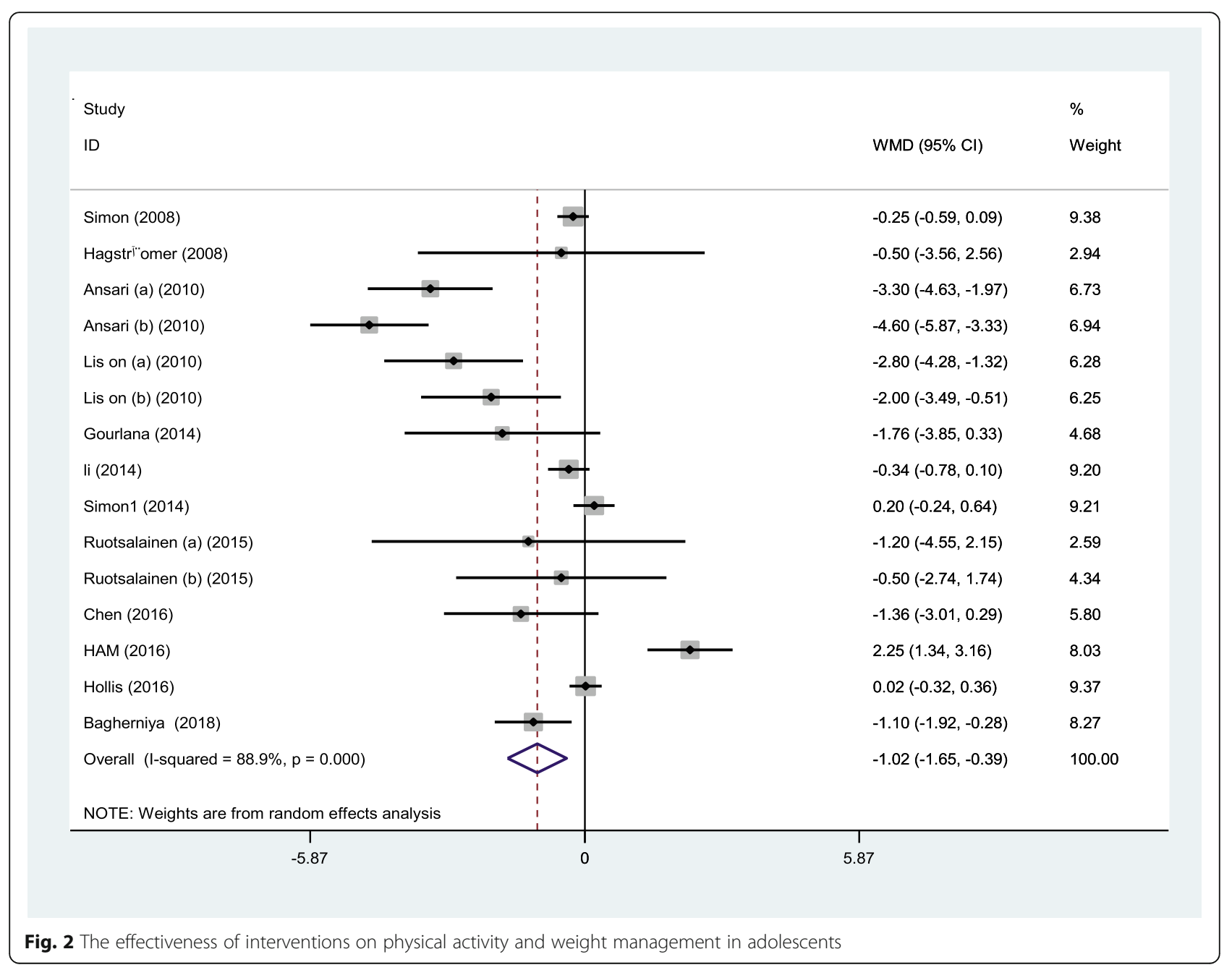




\section{Funnel plot with pseudo $95 \%$ confidence limits}

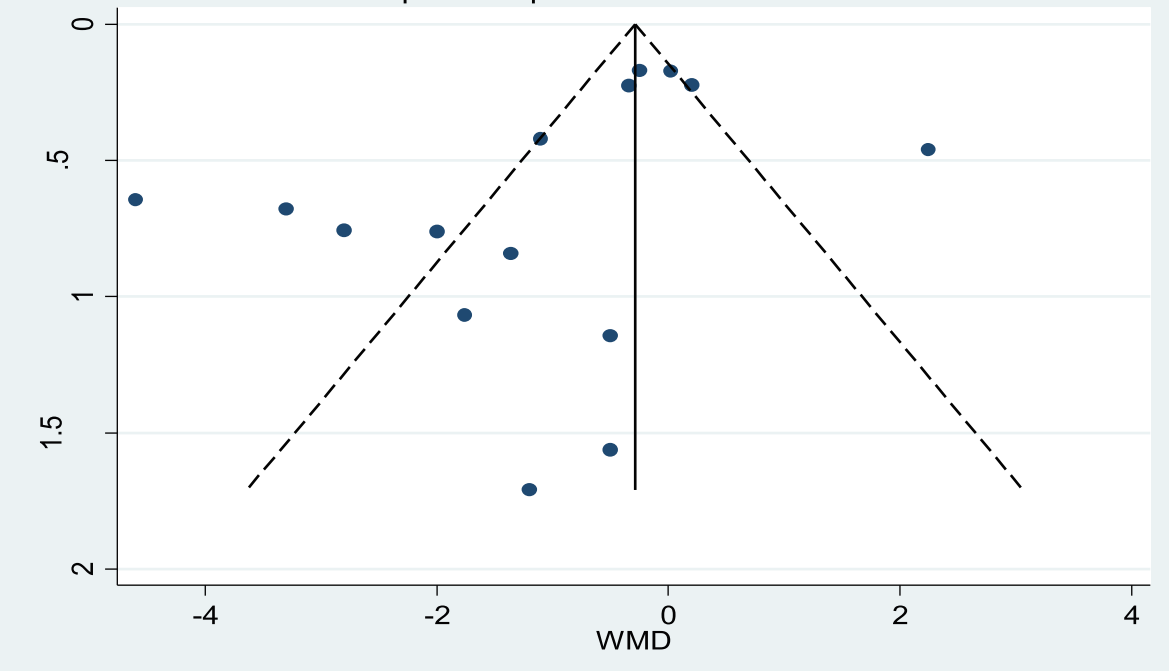

Fig. 3 Funnel plot diagram shows bias in published studies

approaches including awareness-raising and text messaging through mass media mobilization, mass support approach, and school-based interventions were effective in promoting physical activity [44]. The key strategies used in 10 studies [17-19, 23, 24, 28, 30-33] included practical classes of physical activity training, group support, counseling, and e-learning and physical activity behavior were the primary outcome. Weight loss was the secondary outcome and all of these factors can play an important role in promoting the physical activity behavior.

Evidences suggest that the use of multiple support strategies (parental and coaching support), sports coach, long-term intervention, and focusing the intervention solely on physical activity were important [48, 49]. In one study, the authors used a mobile application [36] and in another study, they used Facebook [37] to teach subjects.

The longest follow-up time period of studies reporting favorable intervention effects on PA was 2 weeks [50]. Analysis of groups by follow-up period showed that physical activity behavior was effective for 12-24 months. Therefore, it is recommended to follow this program uninterruptedly for a long period of time. The duration of the intervention in the studies was at least 2 months. The effectiveness in studies that used combined intervention for a longer period of time was higher than one-dimensional interventions [35, 40, 41]. Interventions that used different approaches were more useful than the interventions that focused only on the educational/ behavioral aspect.

To plan effective intervention programs to increase physical activity and weight management, many researchers tried to identify the factors in performing physical activity and removing existing barriers. The most widely used model was the social cognitive model, which was used as a theoretical framework to increase the behavior of regular physical activity and weight management. Educations based on this model promote selfefficacy in overcoming barriers and increasing social support by friends and family [40, 41].

Therefore, it is possible to increase the level of physical activity in educational programs by increasing selfefficacy, skills training, and creating stronger social support [46].

There are many factors involved in failure to do regular physical activity. These barriers include timeconsuming and costly nature, exercise-induced fatigue, and factors such as self-efficacy and support [20]. By providing appropriate education and covering these barriers, adolescents can be encouraged to engage in regular physical activity and weight management.

Many biases may affect the results of a meta-analysis and systematic study. In this study, there was no significant publication-bias. The discrepancies observed in the data due to the differences in the type of interventions and the implementation of interventions in different environments (school, home, hospital) as well as different countries affected the occurrence of a behavior. Studies in which the blindness measures had not been performed had a lower quality score.

There was a difference between the studies and one of the most important differences was the sample size. The difference in sample size could affect the results. The sample size of most of the studies was small [27, 28, 31, $33,35-38$ ] and the duration of follow-up interventions were mostly short. The results measured in the studies 
were mainly based on self-report. The intervention approach in educational studies affected the outcomes as well. Five studies used patterns and theories of behavior change. There were eight RCT studies [29, 31, 35-38, 40, 41], one nRCT study [34], four CCT studies [27, 28, 32, 33], and one experimental study [39]. Four articles had poor quality $[27,28,32,36]$, four articles had medium quality $[35,37,38,40]$, and six articles had a strong quality [29, 31, 33, 34, 39, 41]. The Kappa coefficient was used to evaluate the agreement between the two researchers as to the quality of articles. The agreement between the two researchers was based on six components of the EPHPP tool.

Quality assessment of studies based on criteria; Sample selection bias, study type, confounders, blinding, data collection method, and sample loss and exclusion were also studied. Also, studies were classified into weak, medium, and strong based on these criteria. If other criteria are selected, the quality assessment results may be different. No studies were excluded due to poor quality. One of the most important differences between the studies was the sample size, which affected the results. Also, in most studies, blindness was not performed, which was effective in their quality assessment score.

The reason for the high heterogeneity may be due to differences in the location of the studies, differences in their sample size, and differences in the quality of the studies.

The majority of the selected studies were conducted in high-income countries, indicating that there are fewer research works in low- and middle-income countries on this topic [50]. Moreover, in terms of the type of studies, out of eight articles, seven articles were based on RCT, which emphasizes the problems of conducting RCT studies in low- and middle-income countries. None of the studies examined the effect of economic condition on PA and weight management. It is necessary to study the relationship between socioeconomic status and its relationship to the level of regular physical activity especially in the developing countries.

Interventions based on psychological constructs, especially those based on a psychological theory, were more efficient. Moreover, the duration of follow-up interventions to examine the long-term consequences of studies, the use of approaches other than education, and the simultaneous use of legislative/technological approaches to achieve better results are important. Given that regular physical activity is determined by a wide range of psychological, social, and cultural variables. It is reasonable to consider these factors in interventions designed to improve physical activity in individuals, including self-efficacy, social support, and perceived benefits and barriers [51]. Training increased physical activity by increasing self-efficacy, skills training, and creating more social support.
One of the strengths of this study is the several electronic databases used to search the articles. As to the weaknesses, limitation of the search to electronic databases due to time constraints and failure to encompass the barriers to physical activity (psychological, supportive, information barriers) are notable.

\section{Study limitations}

The results provided a valuable perspective; however, unavailability of the English text of some articles in databases and journals and the inadequate description of the implementation method were among the major limitations. Another limitation was that these studies did not show which component of the intervention was more efficient.

\section{Conclusion}

Health education interventions and programs have a significant impact on regular physical activity. Future works need to address the methodological weaknesses of the current study. Physical activity should be evaluated objectively especially outside of school as diversity of the results affects the quality of studies. Future interventions should include the measurement of psychological structures, especially if they are based on a psychological theory or when psychological mediators are considered. Evidences about the effectiveness of interventions help us designing better interventions (production of appropriate audio-visual print materials in the field of advantages and disadvantages of regular physical activity, types of physical activity, the correct way of physical activity, and its transmission through appropriate channels). Longer follow-ups are needed to study the long-term consequences of interventions. Moreover, larger sample size, approaches other than education, and simultaneous use of legislative/technological approaches to achieve the desired results are recommended.

\section{Appendix}

First line: search for the physical activity part

\#1: Exercises [Mesh Term]

\#2: " Physical Activity" [tw]

\#3: Activities [tw]

\#4: Activity [tw]

\#5:"Physical Exercise" [tw]

\#6:" Physical Exercises" [tw]

\#7:"Acute Exercise"[tw]

Second line: search for weight management

\#9: Weight Loss [Mesh Term]

\#10: Weight Reduction Programs [[Mesh Term]

\#11:" Weight management"[tw]

\# 12: BMI [tw]

$\# 13$ : fat [tw]

\# 14: overweight [tw] 
\#15: obesity [tw]

Third line: Search for the adolescent part

\#17: Adolescent [Mesh Terms]

$\# 18:$ Teen [tw]

\#19: Adolescence [tw]

\#20: Teenagers [tw]

\#21: Youth [tw]

Line 4: Search for the study type section

\#23: "experimental studies" [tw]

\#24: Non-Randomized Controlled Trials as Topic

[Mesh Term]

\#25: Randomized Controlled Trials as Topic [Mesh

Term]

\#26: randomized clinical trial [tw]

\#27: non-randomized clinical trial [tw]

\#28: "follow up studies "[tw]

\#29: "prospective studies"[tw]

\#30: "crossover studies"[tw]

\section{Abbreviation}

WHO: World Health Organization; PRISMA: Preferred Reporting Items for Systematic Reviews and Meta-Analysis; CCT: Controlled clinical trial; RCT: Randomized controlled trial; PICOS: Population, Intervention, Comparison, Outcome, Study type; EPHPP: Effective Public Health Practice Project; BMI: Effective Public Health Practice Project; NCCMT: National Center for Methods and Methods Cooperation

\section{Acknowledgements}

This review is part of the Ph.D thesis in Health education and health promotion. We would like to thank the Vice-chancellor of Hamadan University of Medical Sciences for approval and financial support of this study.

\section{Availability of data and material}

Not applicable.

\section{Authors' contributions}

All authors contributed to the design of the study. For the review, all authors will contribute to the data screening and critical revision, analysis. AG and MA assessment of study quality. AG and BM and MA drafted the manuscript. All authors contributed to, read, and approved the final manuscript.

\section{Funding}

The author(s) disclosed receipt of the following financial support for the research, authorship, and/or publication of this article: This research was funded by a grant from the Hamadan University of Medical Sciences.

\section{Competing interest}

The author(s) declared no potential conflicts of interest with respect to the research, authorship, and/or publication of this article.

\section{Ethics approval and consent to participate}

IR.UMSHA.REC.1397.1046

\section{Consent for publication}

Not applicable.

\section{Author details}

'Social Determinants of Health Research Center, Department of Public health, School of Public health, Hamadan University of Medical Sciences, Hamadan, Iran. ${ }^{2}$ Department of Public health, School of Public health and Research Center for Health Sciences, Hamadan University of Medical Sciences, Hamadan, Iran. ${ }^{3}$ Social Determinants of Health Research Center, Hamadan University of Medical Sciences, Hamadan, Iran. ${ }^{4}$ Department of Epidemiology, School of Public Health and Research Center for Health Sciences, Hamadan University of Medical Sciences, Hamadan, Iran.
${ }^{5}$ Department of Public Health, School of Public Health, Hamadan University of Medical Sciences, Hamadan, Iran.

Received: 14 August 2020 Accepted: 27 January 2021

Published online: 08 February 2021

\section{References}

1. Egger G, Dixon J. Beyond obesity and lifestyle: a review of 21st century chronic disease determinants. BioMed Res Int. 2014;2014:731685. https://doi. org/10.1155/2014/731685.

2. WHO world Health Organisation. Obesity and overweight 2016 [Available from: Cited 2012 May] Available from: URL:http://www.who.int/mediacentre/ factsheets/fs311/en.

3. Organization WHO. Chronic diseases are the major cause of death and disability worldwide. Available from: http. 2018.

4. Takagi D, Nishida Y, DJJopts F. Age-associated changes in the level of physical activity in elderly adults. J Phys Ther Sci. 2015;27(12):3685-7.

5. McGuire LC, Ahluwalia IB, Strine TWJJoWsH. Chronic disease-related behaviors in US older women: Behav Risk Fact Surveillance Syst, 2003. 2006; 15(1):3-7.

6. Mummery WK, Kolt G, Schofield G, McLean G. Associations between physical activity and other lifestyle behaviors in older New Zealanders. J Phys Act Health. 2007:4(4):412-23.

7. Sun F, Norman IJ, While AE. Physical activity in older people: a systematic review. BMC Public Health. 2013;13(1):449.

8. Cooper AR, Goodman A, Page AS, Sherar LB, Esliger DW, van Sluiis EM, et al. Objectively measured physical activity and sedentary time in youth: the International children's accelerometry database (ICAD). Int J Behav Nutr Phys Act. 2015;12(1):1-10.

9. Chau JY, van der Ploeg HP, Merom D, Chey T, Bauman AE. Cross-sectional associations between occupational and leisure-time sitting, physical activity and obesity in working adults. Prevent Med. 2012;54(3-4):195-200.

10. Harrison F, Jones AP. A framework for understanding school based physical environmental influences on childhood obesity. Health Place. 2012;18(3): 639-48.

11. Hales CM, Carroll MD, Fryar CD, Ogden CL. Prevalence of obesity among adults and youth: United States, 2015-2016. 2017.

12. Eisenmann JC. Physical activity and cardiovascular disease risk factors in children and adolescents: an overview. Can J Cardiol. 2004;20(3): 295-301.

13. Shahbazzadeghan B, Farmanbar R, Ghanbari A, Roshan Z. The study of the effects of the regular exercise program on the self-esteem of the elderly in the old people home of rasht. Eur J Soc Sci. 2010;13(2):271-7.

14. Duggal NA, Niemiro G, Harridge SD, Simpson RJ, Lord JM. Can physical activity ameliorate immunosenescence and thereby reduce age-related multi-morbidity? Nat Rev Immunol. 2019;19(9):563-72.

15. Mc S, Kawthur BA. Leisure-time physical activity among university students in Mauritius. Am J Health Res. 2013:1(1):1-8.

16. Ramezankhani A, Tavassoli E, Heydarabadi B. The study of knowledge, attitude and practice towards physical activity college students living on campus in Shahid Beheshti University of Medical Science. Iranian Journal of Health Education and Health Promotion. 1(1).

17. Organization WHO. WHO launches ACTIVE: a toolkit for countries to increase physical activity and reduce noncommunicable diseases. 2018;17:2018.

18. ffectiveness of interventional program based on trans-theoretical model to promote regular physical activity in office workers. 2013.

19. Charkazi A, Fazli L, Alizadeh F, Fazelnia A, Bakhsha F. Regular physical activity based on transtheoretical model among health and paramedic schools of Golestan University of medical sciences. Iran J Health Educ Health Promot. 1(4):57-68.

20. Emdadi S, Hazavehie SMM, Soltanian A, Bashirian S, Moghadam RH. Predictive factors of regular physical activity among middle-aged women in west of Iran, Hamadan: application of PRECEDE model. J Res Health Sci. 2015;15(4):244-9.

21. Patrick K, Norman GJ, Calfas KJ, Sallis JF, Zabinski MF, Rupp J, et al. Diet, physical activity, and sedentary behaviors as risk factors for overweight in adolescence. Arch Pediatr Adolesc Med. 2004;158(4):385-90.

22. Voskuil VR, Frambes DA, Robbins LB. Effect of physical activity interventions for girls on objectively measured outcomes: a systematic review of randomized controlled trials. J Pediatr Health Care. 2017;31(1):75-87. 
23. Pearson N, Braithwaite R, Biddle SJ. The effectiveness of interventions to increase physical activity among adolescent girls: a meta-analysis. Acad Pediatr. 2015;15(1):9-18.

24. Buchan DS, Ollis S, Thomas NE, Baker JS. Physical activity behaviour: an overview of current and emergent theoretical practices. J Obes. 2012;2012: 546459. https://doi.org/10.1155/2012/546459.

25. Moore GF, Audrey S, Barker M, Bond L, Bonell C, Hardeman W, et al. Process evaluation of complex interventions. Med Res Council Guid. 2015:350.

26. Moher D, Shamseer L, Clarke M, Ghersi D, Liberati A, Petticrew M, et al. Preferred reporting items for systematic review and meta-analysis protocols (PRISMA-P) 2015 statement. Syst Rev. 2015;4:1.

27. Lisón JF, Real-Montes JM, Torró I, Arguisuelas MD, Álvarez-Pitti J, MartínezGramage J, et al. Exercise intervention in childhood obesity: a randomized controlled trial comparing hospital-versus home-based groups. Acad Pediatr. 2012:12(4):319-25.

28. Maloney AE, Threlkeld KA, Cook WL. Comparative effectiveness of a 12week physical activity intervention for overweight and obese youth: Exergaming with "dance dance revolution". Res Dev Clin Appl. 2012; 1(2):96-103.

29. Gourlan M, Sarrazin P, Trouilloud D. Motivational interviewing as a way to promote physical activity in obese adolescents: a randomised-controlled trial using self-determination theory as an explanatory framework. Psychol Health. 2013;28(11):1265-86.

30. Corder K, Winpenny E, Love R, Brown HE, White M, Van Sluijs E. Change in physical activity from adolescence to early adulthood: a systematic review and meta-analysis of longitudinal cohort studies. Br J Sports Med. 2019; 53(8):496-503.

31. Simon C, Schweitzer B, Oujaa M, Wagner A, Arveiler D, Triby E, et al. Successful overweight prevention in adolescents by increasing physical activity: a 4-year randomized controlled intervention. Int J Obes. 2008;32(10):1489.

32. Hagströmer M, Elmberg K, Mårild S, Sjöström M. Participation in organized weekly physical exercise in obese adolescents reduced daily physical activity. Acta Paediatr. 2009;98(2):352-4.

33. El Ansari W, El Ashker S, Moseley L. Associations between physical activity and health parameters in adolescent pupils in Egypt. Int J Environ Res Public Health. 2010;7(4):1649-69.

34. Li X-H, Lin S, Guo H, Huang Y, Wu L, Zhang Z, et al. Effectiveness of a school-based physical activity intervention on obesity in school children: a nonrandomized controlled trial. BMC Public Health. 2014;14(1):1282.

35. Simon C, Kellou N, Dugas J, Platat C, Copin N, Schweitzer B, et al. A socioecological approach promoting physical activity and limiting sedentary behavior in adolescence showed weight benefits maintained 2.5 years after intervention cessation. Int J Obes. 2014;38(7):936.

36. Direito A, Jiang Y, Whittaker R, Maddison R. Apps for IMproving FITness and increasing physical activity among young people: the AIMFIT pragmatic randomized controlled trial. J Med Int Res. 2015;17(8):e210.

37. Ruotsalainen $H$, Kyngäs $H$, Tammelin $T$, Heikkinen $H$, Kääriäinen $M$. Effectiveness of Facebook-delivered lifestyle counselling and physical activity self-monitoring on physical activity and body mass index in overweight and obese adolescents: a randomized controlled trial. Nurs Res Pract 2015;2015.

38. Chen S-R, Tseng C-L, Kuo S-Y, Chang Y-K. Effects of a physical activity intervention on autonomic and executive functions in obese young adolescents: a randomized controlled trial. Health Psychol. 2016;35(10):1120.

39. Ham OK, Sung KM, Lee BG, Choi HW, Im E-O. Transtheoretical model based exercise counseling combined with music skipping rope exercise on childhood obesity. Asian Nurs Res. 2016;10(2):116-22.

40. Hollis J, Sutherland R, Campbell L, Morgan P, Lubans D, Nathan N, et al. Effects of a 'school-based'physical activity intervention on adiposity in adolescents from economically disadvantaged communities: secondary outcomes of the 'Physical Activity 4 Everyone'RCT. Int J Obes. 2016;40(10):1486.

41. Bagherniya M, Mostafavi Darani F, Sharma M, Maracy MR, Allipour Birgani R, Ranjbar G, et al. Assessment of the efficacy of physical activity level and lifestyle behavior interventions applying social cognitive theory for overweight and obese girl adolescents. J Res Health Sci. 2018;18(2).

42. Schuck P. Assessing reproducibility for interval data in health-related quality of life questionnaires: which coefficient should be used? Qual Life Res. 2004; 13(3):571-85.

43. Ranjani H, Pradeepa R, Mehreen T, Anjana RM, Anand K, Garg R, et al. Determinants, consequences and prevention of childhood overweight and obesity: an Indian context. Ind J Endocrinol Metab. 2014;18(Suppl 1):S17.
44. Kelishadi R, Haghdoost A-A, Sadeghirad B, Khajehkazemi R. Trend in the prevalence of obesity and overweight among Iranian children and adolescents: a systematic review and meta-analysis. Nutrition. 2014;30(4): 393-400.

45. Mears R, RJBJoSM J. Effectiveness of after-school interventions at increasing moderate-to-vigorous physical activity levels in 5-to 18-year olds: a systematic review and meta-analysis. 2016;50(21):1315-24.

46. Rostami-Moez M, Rezapur-Shahkolai F, Hazavehei SMM, Karami M, KarimiShahanjarini A, Nazem F. Effect of educational program, based on PRECEDE and trans-theoretical models, on preventing decline in regular physical activity and improving it among students. J Res Health Sci. 2017;17(2):375

47. Kelishadi R, Ghatrehsamani S, Hosseini M, Mirmoghtadaee P, Mansouri S, Poursafa P. Barriers to physical activity in a population-based sample of children and adolescents in Isfahan, Iran. Int J Prev Med. 2010;1(2):131.

48. Sepidarkish M, Nedjat S, Haghjou L, Mounesan L, Shokri F, Almasi-Hashiani A, et al. Characteristics of a school-based program to promote physical activity in adolescents and interventional framework: a qualitative study. 2017;5(2):90-101.

49. Bentley GF, Goodred JK, Jago R, Sebire SJ, Lucas PJ, Fox KR, et al. Parents' views on child physical activity and their implications for physical activity parenting interventions: a qualitative study. BMC Pediatr. 2012;12(1):1-9.

50. Corder K, Winpenny E, Love R, Brown HE, White M, Sluijs EV. Change in physical activity from adolescence to early adulthood: a systematic review and meta-analysis of longitudinal cohort studies. Br J Sports Med. 2019; 53(8):496-503.

51. Kaczynski AT, Bopp MJ, Wittman P. Peer reviewed: association of workplace supports with active commuting. Preventing chronic disease. Prev Chronic Dis. 2010;7(6).

\section{Publisher's Note}

Springer Nature remains neutral with regard to jurisdictional claims in published maps and institutional affiliations.

Ready to submit your research? Choose BMC and benefit from:

- fast, convenient online submission

- thorough peer review by experienced researchers in your field

- rapid publication on acceptance

- support for research data, including large and complex data types

- gold Open Access which fosters wider collaboration and increased citations

- maximum visibility for your research: over $100 \mathrm{M}$ website views per year

At $\mathrm{BMC}$, research is always in progress.

Learn more biomedcentral.com/submission 